Discussion Papers in

Economics and Econometrics

2000

This paper is available on our website http://www/soton.ac.uk/ econweb/dp/dp00.html 


\title{
The Quality of Life in England and Wales*
}

\author{
Sylaja Srinivasan Geoff Stewart \\ Department of Economics \\ University of Southampton
}

August 14, 2000

\begin{abstract}
Local amenities play an important role in determining where we choose to live and our overall quality of life. In many cases, however, amenities do not have prices and will therefore be underprovided by the market. In this paper, we use individual and county level data for England and Wales to estimate implicit amenity prices and to calculate an index of quality of life for each county. Among our findings is a large negative price on air pollution. The range in quality of life across counties is estimated to be in excess of two thousand pounds per year.
\end{abstract}

JEL Classification: I31, R1

Keywords: Quality of Life index, amenities, hedonic prices.

Address for Correspondence: Geoff Stewart, Department of Economics, University of Southampton, Highfield, Southampton SO17 1BJ, U.K. Tel: +44 (0)23 8059 2520; Fax: +44(0)238059 3858; e-mail: gs@soton.ac.uk

*We wish to thank Sujoy Mukerji, Raymond O'Brien and Jackline Wahba for helpful comments. We are very grateful to David Martin for help with ARC/INFO and to David Doulton for computing support. We would also like to thank AEA Technology and the Climatic Research Unit, University of East Anglia for providing data. 


\section{Introduction}

Our quality of life depends on where we live. But just how much value do we put on a good location? And what are the factors that determine the attractiveness of an area? These questions, interesting in themselves, derive added importance from the fact that a number of potentially important amenities - for instance, clean air - do not have prices and will therefore be underprovided by the market. Furthermore, the absence of prices creates difficulties for the design of policies to deal with this inefficiency; indeed, to the extent that policy tends to focus on variables that are relatively easy to measure, government intervention may actually have an adverse impact on amenity provision. In the UK, the government itself has recently argued that various dimensions of the quality of life have suffered as a consequence of the reliance on GDP as a measure of economic success. Its proposed response incorporates a commitment to publish data on some 150 quality of life indicators, ranging from average life expectancy to populations of wild birds. ${ }^{1}$ This clearly marks an important first step in tackling the problem. However, to address the inevitable policy trade-offs it is necessary to consider how much weight people put on each of the contributors to their quality of life; ideally these preferences would be expressed in monetary terms. A set of weights would also be required to aggregate the individual elements into an overall measure of quality of life.

In a seminal contribution to the theoretical literature on the quality of life, Roback (1982) showed how the locational decisions of individuals and firms lead to an equilibrium in which differences in amenity levels are reflected in wage and house price differentials, and that these differentials can then be used to estimate monetary valuations - 'implicit prices' - for each amenity. Thus the relative value of each component of quality of life is inferred from individuals' actual decisions in labour and housing markets. In this paper, we apply Roback's model to county level data for England and Wales. Among our findings are a large negative price on air pollution and, perhaps surprisingly, a positive price on population density. The set of implicit prices is then used to calculate an index of the overall quality of life in each of the counties. This points to considerable variation across England and Wales: for the represen-

\footnotetext{
${ }^{1}$ Department of the Environment, Transport and the Regions (1999).
} 
tative household, the difference in quality of life between the top-ranked and bottom-ranked county is estimated to be well in excess of two thousand pounds per year.

Amenity pricing and the measurement of quality of life has attracted considerable interest in the US. Early empirical work derived implicit amenity prices from data on either residential property values or wages. For example, Ridker and Henning (1967) estimated that variations in air pollution levels explained 1.2 per cent of the variance in house prices in St. Louis. More ambitiously, Nordhaus and Tobin (1972) used estimates of implicit prices based on wage data to calculate the cost of urbanisation to the entire US economy. The first study to construct a quality of life ranking on the basis of amenity prices was Rosen (1979). He used census data on wages and characteristics of almost nine thousand individuals to estimate implicit prices for pollution, crime, climate, and measures of crowding and labour market conditions. These prices were then combined with the quantities of each amenity to produce quality of life index values for fifteen major US cities.

A major theoretical contribution to the literature was provided by Roback's (1982) general equilibrium model of individual and firm location. Drawing upon Rosen (1974), she showed how wages and land prices are simultaneously determined by the location decisions of workers and firms and that both wage and rent gradients are required in order to determine the implicit price of an amenity. Roback applied her model to data on individuals' wages and average land prices to produce estimates of implicit amenity prices and a ranking of twenty of the largest US cities. Using the same methodology, but more detailed data, Blomquist, Berger and Hoehn (1988) examined the quality of life in 253 US urban counties in 1980. Their results suggest strongly that compensation for amenity effects occurs in both labour and housing markets. Moreover, the amounts involved were large: the estimated difference in quality of life between the top-ranked county (Pueblo) and the bottom-ranked (St. Louis City) was $\$ 5146$ per household per year in 1980. Subsequent empirical work in the US has extended the analysis in various directions. For example, Gyourko and Tracy (1991) introduced the effect of local fiscal conditions, and Clark and Nieves (1995) incorporated detailed data on nuclear plants, petrochemical refineries and other noxious facilities.

In Britain, empirical work has been hampered by data limitations. The only previous 
estimates of amenity values using the Roback framework are those of Maddison (1997), which are derived using county level average wage and house price data. In this paper,by contrast, we use individual level data which allows us to control for the effect of personal characteristics, occupation and industry on wages. Similarly, our house price data is disaggregated by property type and therefore permits a degree of control for quality differences. In addition, we have been able to incorporate a measure of air quality among the amenities. It was constructed from recent estimates, produced by AEA Technology, of the level of airborne particulates in each $1 \mathrm{~km}$ square within the UK. ${ }^{2}$ Previously, information was limited to air quality levels recorded at dispersed monitoring sites, and did not therefore permit the construction of meaningful regional data.

The following section outlines the theoretical framework and describes the data. Section 3 explains the method of estimation and reports the results on amenity prices and the quality of life index. A short concluding section completes the paper.

\section{Model and data}

The starting point for Roback's (1982) theoretical analysis of the quality of life is an assumption that both labour and capital are perfectly mobile across regions. Actual or potential migration thus generates an equilibrium in which individuals and firms are indifferent between locations. An implication is that, in equilibrium, variations in amenity levels across regions must be reflected in compensating wage and/or land prices. The size of the differentials depends, in part, on individual preferences and Roback demonstrates how estimates of willingness to pay for each amenity can be derived from data on wages and land rents. In the basic version of the model, individuals derive utility from a composite good, land and local amenities. This generates an expression for amenity prices that includes the land rent. Our data, however, is on housing expenditures rather than land prices, and therefore we follow Blomquist, Berger and Hoehn (1988) and Gyourko and Tracy (1991) in drawing upon an extended version of the model that incorporates the housing sector. Similarly, we treat households, rather than individuals, as a basic unit of analysis.

\footnotetext{
${ }^{2}$ For details, see Stedman, Campbell and Vincent (1997).
} 
Identical households are endowed with one unit of labour and gain utility from a composite good, housing services and local amenities. In equilibrium, household utility is the same in all locations. This can be expressed in terms of the indirect utility function:

$$
v\left(w_{k}, h_{k} ; a_{k}\right)=v^{0}
$$

where the subscript $k$ refers to regions, $w_{k}$ denotes the wage rate, $h_{k}$ the price of housing, and $a_{k}$ a vector of amenities.

Firms produce the composite good using labour and land with a constant returns to scale production function. The product is sold at a price normalised to unity and, in equilibrium, unit costs are equal in all locations:

$$
c\left(w_{k}, r_{k} ; a_{k}\right)=1
$$

where $r_{k}$ denotes the price of land.

Housing is similarly produced under constant returns to scale, with unit costs equated to the price, $h_{k}$ :

$$
h\left(w_{k}, r_{k} ; a_{k}\right)=h_{k}
$$

Equations (1), (2), and (3) determine the wage, price of land and price of housing associated with the level of amenities in a particular region. Our interest is in the value of amenities to households as measured by willingness to pay. Let $P_{k}$ denote the amount of income required to compensate for a small change in amenity level. Totally differentiating (1) and using Roy's identity, we obtain: ${ }^{3}$

$$
P_{k} \equiv \frac{v_{a}}{v_{w}}=\theta_{k} \frac{d h_{k}}{d a_{k}}-\frac{d w_{k}}{d a_{k}}
$$

where $\theta_{k}$ is the quantity of housing purchased.

Following Blomquist, Berger and Hoehn (1988) and Gyourko and Tracy (1991), the first term on the right-hand side is approximated by $\frac{d H_{k}}{d a_{k}}$, where $H_{k}$ is housing expenditure. ${ }^{4}$ Estimates of $\frac{d H_{k}}{d a_{k}}$ and $\frac{d w_{k}}{d a_{k}}$ are obtained from our data using the following empirical model:

\footnotetext{
${ }^{3}$ This is equation (6) in Blomquist, Berger and Hoehn (1988).

${ }^{4}$ The approximation is exact if $\theta_{k}$ is constant.
} 


$$
\begin{aligned}
& w_{i k}=f\left(x_{i}, a_{k}, \varepsilon_{i k}\right) \\
& H_{j k}=g\left(z_{j}, a_{k}, \eta_{j k}\right)
\end{aligned}
$$

where the subscript $i$ refers to individuals, $j$ to properties, and $k$ to counties; $w_{i k}$ is the hourly wage of individual $i$ in county $k$, and $x_{i}$ a vector of individual worker traits; $H_{j k}$ is the average annual housing expenditure on property $j$ in county $k ; z_{j}$ is the property type; and $\varepsilon_{i k}$ and $\eta_{j k}$ are the usual disturbance terms.

Whilst the theoretical model treats households as the basic unit of analysis, our data comprise the (hourly) wages and characteristics of individuals. The procedure we adopt is to estimate (5) using individuals' hourly wages and then translate the resulting coefficients into annual household values using the sample mean values of hours worked per week, weeks worked per year and number of workers per household. Equation (4) shows how the wage and housing expenditure coefficients are then combined to yield the implicit price of each amenity. It is important to note that whilst locational attributes that enhance utility should have a positive price, and undesirable attributes a negative price, the signs in the underlying wage and housing expenditure equations may be ambiguous. For example, suppose that both individuals and firms value sunshine. For individuals, locational equilibrium requires that locations with more sunshine have either lower wages or higher house prices, or both. By contrast, the requirement for equilibrium among firms is that the sunny locations have either higher wages or higher house prices, or both. Thus whilst the model would predict that sunny locations have higher house prices, the effect on wages is ambiguous.

Data were collected for 55 counties in England and Wales. ${ }^{5}$ The house price data, obtained from HM Land Registry, comprise the average selling price in 1995, by county, for each of four residential property types: detached, semi-detached, terraced, and flat/maisonette. These prices were then converted to housing expenditures using information on mortgage rates. Information on the wages, personal characteristics, and county of residence of 12,320 individ-

\footnotetext{
${ }^{5}$ Details of all data manipulations, together with a map of the 55 counties, are contained in the appendix.
} 
uals was obtained from 1995 Quarterly Labour Force Surveys (QLFS) ${ }^{6}$. The set of personal characteristics are the standard explanatory variables in wage equations: gender, position in household, ethnic status, marital status, education, work experience, part-time or full-time, private or public sector, occupation and industry. Drawing on the US literature, we examine five classes of amenity: air quality, climate, educational provision, unemployment rate and population density.

Air quality is measured using estimates of levels of airborne particles, $P M_{10}$, provided by AEA Technology. $P M_{10}$ is designed to measure those particulates that are likely to be inhaled into the lungs; specifically, it is the mass of material deposited in a sampler that selects smaller particles preferentially. An indication of its importance for quality of life is the recommendation, in 1995, of the Expert Panel on Air Quality Standards that, on health grounds, the UK Government should aim to reduce both peak and annual average concentrations. For our purposes, it is also important to note that particulate levels are an aspect of air quality on which individuals are likely to be relatively well-informed. Moreover, welfare may be sensitive to the process that generates the particulates - for instance, road traffic - as well as the particulates themselves; we return to this point later. Levels of $P M_{10}$ recorded at monitoring sites across the UK have been translated by AEA Technology into annual mean estimates on a $1 \mathrm{~km}$ grid. We converted this grid data into mean values for each county using 1991 Census digitalised boundary data. ${ }^{7}$

Information on hours of sunshine, precipitation, frost days ${ }^{8}$, and mean temperature was provided by the Climatic Research Unit at the University of East Anglia. This took the form of monthly averages over the period 1961-1990 on a 10km grid. We converted the data into annual averages and then we used the Census boundary data to map the grid data into county means.

We consider two measures of educational provision: an average of the pupil-teacher ratio

\footnotetext{
${ }^{6}$ The QLFS from 1994 includes a county of residence code for each individual. This allows us to match individuals to the amenity data. The sample was restricted to individuals aged 16 and over.

${ }^{7}$ The digitalised boundary data was obtained from EDINA and conversion carried out using ARC/INFO.

${ }^{8} \mathrm{~A}$ frost day is a day when the grass minimum temperature falls below $0^{\circ} \mathrm{C}$.
} 
in primary and secondary schools, and the number of day nursery places ${ }^{9}$ per 1000 population aged under 5 years. These data together with the unemployment rate and population density, were obtained from the Office for National Statistics.

\section{Estimation and results}

Box-Cox searches were conducted to determine the functional form of equations (5) and (6). The searches were carried out over values of $\lambda$ in

$$
\frac{Y^{\lambda}-1}{\lambda}=b_{0}+\sum b_{l} X_{l}
$$

where $Y$ is either the wage rate or housing expenditure and $X_{l}$ are the independent variables (amenities and personal characteristics in the wage equation and amenities and property type dummies in the housing equation). The values that maximised the log-likelihood functions were $\lambda=0.1$ in the wage equation and $\lambda=-0.2$ in the housing equation.

Table 1 presents results for two versions of the model. In the first, the wage and housing expenditure equations are estimated with the full set of amenities described above. The resulting coefficients, and associated t-statistics, are presented in columns 1 and $2 .{ }^{10}$ The annualised household wage component is shown in column 3, and this is then combined with column 2 - as indicated by equation (4) above - to yield the implicit prices in column $4 .{ }^{11}$ These prices represent the amount that the average household is willing to pay for the amenity at the margin (in 1995 prices).

As a group, the amenities are highly statistically significant in both the wage and housing expenditure equations. ${ }^{12}$ Individually, five of the amenities are statistically significant at the $1 \%$ level or better in at least one of the equations. The exceptions are three of the climate

\footnotetext{
${ }^{9}$ Only local authority provided and registered day nurseries.

${ }^{10}$ Findings for individual worker characteristics and housing types are reported in the appendix.

${ }^{11}$ The housing expenditure component is simply the linearised regression coefficient. Linearisation was carried out as follows: $b^{\prime}=b y^{(1-\lambda)}$ where $b^{\prime}$ is the linearised coefficient, $b$ the regression coefficient and $y$ is the sample mean annual housing expenditure or hourly wage. The wage component is the linearised coefficient multiplied by the product of average hours per week (38.34), weeks per year (45.63) and workers per household (1.29).

${ }^{12}$ Likelihood ratio tests indicate that the amenities are jointly significant at above the $1 \%$ level in both equations. Full details are presented in the appendix.
} 
Table 1: Regression Results and Hedonic Price Estimates

\begin{tabular}{|c|c|c|c|c|c|c|c|c|}
\hline \multirow[t]{3}{*}{ Amenity } & \multirow{2}{*}{\multicolumn{2}{|c|}{$\begin{array}{l}\text { Hourly Wage } \\
\text { Hedonic }\end{array}$}} & \multirow{2}{*}{\multicolumn{2}{|c|}{$\begin{array}{c}\text { Annual Housing } \\
\text { Expenditure Hedonic }\end{array}$}} & \multicolumn{4}{|c|}{ Annualized Household Values $(£)$} \\
\hline & & & & & \multirow{2}{*}{$\begin{array}{c}\text { Wage Component } \\
(3)\end{array}$} & \multirow[b]{2}{*}{$\left(3^{\prime}\right)$} & \multirow{2}{*}{$\begin{array}{c}\text { Implicit Price } \\
(4)\end{array}$} & \multirow[b]{2}{*}{$\left(4^{\prime}\right)$} \\
\hline & (1) & $\left(1^{\prime}\right)$ & $(2)$ & $\left(2^{\prime}\right)$ & & & & \\
\hline $\mathrm{PM}_{10}$ (particulates) & $\frac{0.2207}{(5.36)}$ & $\frac{0.2108}{(7.61)}$ & $-\underset{(0.33)}{21.3767}$ & $\begin{array}{c}7.8875 \\
(0.20)\end{array}$ & $\underset{(5.36)}{498.04}$ & $\begin{array}{c}475.72 \\
(0.20)\end{array}$ & -519.42 & -467.84 \\
\hline Sunshine & $\underset{(1.69)}{0.0010}$ & $\begin{array}{l}0.0013 \\
(4.18)\end{array}$ & $\begin{array}{l}3.9285 \\
(4.11)\end{array}$ & $\underset{(6.77)}{3.7925}$ & $\begin{array}{l}2.27 \\
(1.69)\end{array}$ & $\begin{array}{l}3.021 \\
(6.77)\end{array}$ & 1.66 & 0.77 \\
\hline Precipitation & $\underset{(0.59)}{0.0001}$ & & $-\underset{(0.60)}{0.1783}$ & & $\begin{array}{l}0.26 \\
(0.59)\end{array}$ & & -0.44 & \\
\hline Frost Days & -0.0007 & & -0.8065 & & $\begin{array}{c}-1.60 \\
(0.19)\end{array}$ & & 0.79 & \\
\hline Temperature & $\frac{0.0782}{(0.82)}$ & & $\begin{array}{c}-24.7958 \\
(0.17)\end{array}$ & & $\begin{array}{c}176.43 \\
(0.82)\end{array}$ & & -201.23 & \\
\hline Pupil Teacher Ratio & $\underset{(0.90)}{0.0683}$ & & $\begin{array}{l}49.9759 \\
(0.61)\end{array}$ & & $\underset{(0.90)}{154.12}$ & & -104.14 & \\
\hline Nursery Places & $-\underset{(2.01)}{0.0046}$ & $-\underset{(1.73)}{0.0037}$ & $\underset{(0.28)}{-1.0268}$ & $\begin{array}{c}-0.1908 \\
(0.05)\end{array}$ & $\begin{array}{c}-10.29 \\
(2.01)\end{array}$ & $\begin{array}{l}-8.38 \\
(0.05)\end{array}$ & 9.26 & 8.18 \\
\hline Population Density & $\frac{0.0002}{(3.85)}$ & $\underset{(4.30)}{0.0002}$ & $\underset{(9.57)}{0.8332}$ & $\begin{array}{c}0.7879 \\
(10.52)\end{array}$ & $\begin{array}{l}0.42 \\
(3.85)\end{array}$ & $\begin{array}{c}0.41 \\
(10.52)\end{array}$ & 0.42 & 0.38 \\
\hline Unemployment Rate & $\underset{(6.20)}{0.1279}$ & $-\underset{(6.65)}{0.1219}$ & $-\underset{(10.72)}{304.0741}$ & $-\underset{(12.08)}{292.7231}$ & $-\underset{(6.20)}{288.60}$ & $\begin{array}{c}-275.02 \\
(12.08)\end{array}$ & -15.47 & -17.71 \\
\hline Log-Likelihood & -30066.6 & -30067.4 & -1724.14 & -1724.93 & & & & \\
\hline Number of Obs. & 12320 & 12320 & 220 & 220 & & & & \\
\hline
\end{tabular}

t-statistics are in parentheses. Columns $(1),\left(1^{\prime}\right),(2)$ and $\left(2^{\prime}\right)$ are linearised coefficients from the Box-Cox procedure. The

annualized household wage components were calculated by multiplying (1) and (1') by sample mean hours per week (38.34), weeks per year (45.63) and workers per household (1.29); Column (4) is (2) - (3). Column $\left(4^{\prime}\right)$ is $\left(2^{\prime}\right)-\left(3^{\prime}\right)$. 
variables - precipitation, temperature and frost days - and the pupil-teacher ratio. The climate variables exhibit multicollinearity for obvious reasons; in the case of the pupil-teacher ratio, the lack of significance may indicate that county level data is too coarse to detect an effect on wages or house prices. The quality of primary and secondary education varies considerably within each of the counties, and therefore may influence the choice of location within, rather than between, counties. In the light of these considerations, the model was re-estimated without precipitation, temperature, frost days and the pupil-teacher ratio. The results, presented in columns 1', 2', 3'and 4', indicate that the change in specification has little impact on either the wage and housing expenditure coefficients or, more importantly, the implicit prices. Moreover, as we shall see later, the quality of life ranking is robust to the change. For the remainder of the paper we focus discussion on the second version of the model.

When interpreting the results, it is important to recall that whilst locational traits that enhance utility should have a positive price, and undesirable traits a negative price, the underlying wage and housing expenditure coefficients may be ambiguous in sign.

The negative price of airborne particles, $P M_{10}$, conforms with a priori expectations. One question that arises is whether this result reflects not just a distaste for poor air quality, but also a response to other externalities - such as noise and visual intrusion - associated with the production of $P M_{10}$. In the UK, in 1995, the main sources of $P M_{10}$ emissions were road transport $(26 \%)$, power stations $(15 \%)$ and iron and steel production (9\%). Refineries, construction, mining, quarrying and 'other industrial processes' together accounted for a further $37 \%$ of the total. Each of these activities is clearly capable of generating a variety of forms of externality. However, airborne particles are, by nature, highly mobile - especially when emitted from industrial chimneys. Detection may therefore take place some distance from the point of emission, thereby limiting the degree to which our measure of air quality is acting as a proxy for other variables.

We find that sunshine makes a positive contribution to the quality of life in England and Wales as, not surprisingly, does the level of nursery provision. Unemployment, similarly, has its expected negative price. Population density is difficult to sign a priori because, as Rosen (1979) points out, it is likely to proxy various unmeasured factors in addition to any taste or 
distaste for density as such. Thus its positive price may, in part, reflect the fact that regions which are more densely populated can support a wider range of consumption activities.

These results are in line with existing research. For Britain, Maddison (1997), using different data on wages and house prices, similarly found that sunshine and population density made a positive contribution to the quality of life, whereas unemployment had a negative effect. Whilst nursery provision was not examined, he did find that the proportion of children who passed five or more GCSEs had a positive price.

Our estimates of the impact of airborne particulates on the quality of life are the first for the UK. For the US, Roback (1982), Blomquist, Berger and Hoehn (1988) and Gyourko and Tracy (1991) all found that particulates had a negative price. In addition, their results suggest that, as in England and Wales, both sunshine and population density make a positive contribution to the quality of life. ${ }^{13}$

The implicit prices in Table 1 are used to construct quality of life (QOL) index values for each county as follows:

$$
Q O L_{k}=\sum P_{m}^{*} a_{m k}
$$

where $P_{m}^{*}$ is the implicit price of amenity $m$ and $a_{m k}$ is the quantity of amenity $m$ in county $k$.

We have standardised on a hypothetical county which has the sample mean quantity of each amenity. Table 2 presents the standardised quality of life index value for each county, in descending order. The top-ranked county is Cumbria in the north-west of England, followed by Dyfed in Wales and then Somerset in the south-west of England. The standardised QOL index value for Cumbria is $£ 1169$, which represents the amount that the average household would be willing to pay per year to live in Cumbria rather than the hypothetical average county. At the other end of the scale is Bedfordshire with a value of $£-1194$, giving an overall QOL range in England and Wales of $£ 2363$ per annum. It is important to bear in mind that these results do not imply any tendency for migration from low to high-ranked counties. The model is an equilibrium one in which counties that are ranked highly in terms of QOL have

\footnotetext{
${ }^{13}$ All three US studies find that hours of sunshine has a positive price. Roback is the only one of the three to include population density among the regressors.
} 
Table 2: Quality of Life by County

\begin{tabular}{|c|c|c|c|c|c|}
\hline County & Ranking & Index Value & County & Ranking & Index Value \\
\hline Cumbria & 1 & 1169 & Derbyshire & 29 & -137 \\
\hline Dyfed & 2 & 1147 & Inner London & 30 & -174 \\
\hline Somerset & 3 & 1019 & Humberside & 31 & -180 \\
\hline Gwynedd & 4 & 1014 & W. Yorkshire & 32 & -305 \\
\hline Northumberland & 5 & 933 & E. Sussex & 33 & -350 \\
\hline Clwyd & 6 & 913 & W. Sussex & 34 & -373 \\
\hline Devon & 7 & 870 & Oxfordshire & 35 & -382 \\
\hline W. Glamorgan & 8 & 837 & W. Midlands & 36 & -390 \\
\hline Powys & 9 & 808 & Cleveland & 37 & -404 \\
\hline Corwall & 10 & 797 & Cambridgeshire & 38 & -430 \\
\hline S. Glamorgan & 11 & 776 & Hampshire & 39 & -455 \\
\hline Mid-Glamorgan & 12 & 721 & Northamptonshire & 40 & -457 \\
\hline Lancashire & 13 & 675 & Warwickshire & 41 & -497 \\
\hline Hereford \& Worcester & 14 & 645 & Leicestershire & 42 & -515 \\
\hline Dorset & 15 & 579 & Nottinghamshire & 43 & -523 \\
\hline Durham & 16 & 567 & Lincolnshire & 44 & -545 \\
\hline Cheshire & 17 & 541 & Buckinghamshire & 45 & -545 \\
\hline Shropshire & 18 & 376 & Kent & 46 & -590 \\
\hline N. Yorkshire & 19 & 348 & S. Yorkshire & 47 & -610 \\
\hline Avon & 20 & 290 & Berkshire & 48 & -735 \\
\hline Gwent & 21 & 247 & Surrey & 49 & -851 \\
\hline Greater Manchester & 22 & 142 & Essex & 50 & -869 \\
\hline Gloucestershire & 23 & 108 & Hertfordshire & 51 & -917 \\
\hline Merseyside & 24 & 86 & Outer London & 52 & -976 \\
\hline Wiltshire & 25 & 6 & Suffolk & 53 & -1069 \\
\hline Tyne and Wear & 26 & 3 & Norfolk & 54 & -1090 \\
\hline Staffordshire & 27 & -4 & Bedfordshire & 55 & -1194 \\
\hline Isle of Wight & 28 & -49 & & & \\
\hline
\end{tabular}

Index values have been rounded to integers and normalized on a hypothetical county with sample mean amenity values. 
Table 3: Impact of Amenities on Quality of Life

\begin{tabular}{lcc}
\hline \hline \multicolumn{1}{c}{ Amenity } & Value Range $(£)$ & Inter-quartile Range $(£)$ \\
& & \\
\hline & & \\
PM $_{10}$ (particulates) & 4678.35 & 935.67 \\
Sunshine & 395.69 & 136.33 \\
Nursery Places & 557.32 & 200.91 \\
Population Density & 3173.47 & 154.69 \\
Unemployment Rate & 216.02 & 59.32 \\
& & \\
\hline
\end{tabular}

correspondingly higher house prices and/or lower wage rates.

To help understand the ranking, we first consider the relative contribution of each amenity to the QOL index, and then look at the pattern of amenities across counties.

An indication of the contribution of each amenity to the QOL index is the amount that a household would be willing to pay to move from the county with the lowest amount of a particular amenity to the county with the highest. This range is presented in column 2 of Table 3 , and suggests that the main contributors to the index are the measure of air quality (a range of £4678) and population density (a range of £3173). The contributions of the remaining three variables are appreciably smaller; the next largest being nursery provision with a range of $£ 557$, followed by sunshine, £396, and unemployment, £ 216. The ranges for both air quality and population density are substantially higher than the overall QOL range of $£ 2363$, reflecting a tendency for good air quality to be associated with low population density. The inter-quartile range, in column 3, confirms the importance of air quality but reveals that towards the centre of the distribution the relative contribution of population density is diminished.

Table 4 presents the overall QOL ranking together with rankings for each of the amenities. For each amenity, the numbers indicate the preference ranking; thus, for $P M_{10}$ number 1 is assigned to the county with the lowest level (because it has a negative price), but for sunshine (which has a positive price) number 1 indicates the highest number of hours. The most striking characteristic of the counties at the top of the overall ranking is that they enjoy good air quality: of the top ten QOL counties, eight are ranked among the ten best for air quality. 
They also tend to be characterised by low population densities, with seven of the top ten overall being among the ten with the lowest densities. In other respects the counties at the top exhibit considerable variation. For instance, they include the fifth and fifty-fourth ranked counties in terms of sunshine, the fourth and forty-ninth in terms of unemployment, and the ninth and fifty-first in terms of nursery provision. This heterogeneity is not unexpected given that these amenities have small value ranges relative to air quality and population density.

The ten counties at the bottom of the QOL ranking are not quite a mirror image of those at the top. They are characterised by poor air quality, but there is little uniformity in population density. The group includes Outer London, which has the second highest density, but also Suffolk and Norfolk, which have very low densities. In fact, only Outer London and South Yorkshire from this group feature among the ten counties with the highest population density. With regard to the other amenities, the picture is mixed. As well as counties that perform poorly, the group includes Kent, which is third in the list of nursery provision and sixth in the sunshine ranking, and Surrey, which has the lowest unemployment rate of all regions.

The correlation between air quality and overall QOL, whilst strong, is by no means perfect. For instance, both Inner London and Greater Manchester achieve a QOL rank more than twenty places above their respective air quality rankings. In the case of Inner London, the explanation lies in good nursery provision, plenty of sunshine and, most importantly, a high population density. The density in Inner London, just over eight thousand three hundred people per square kilometre, is more than twice the figure in the next most densely populated region. Greater Manchester also benefits from good nursery provision and a high density (almost twice as high as the next county in the density ranking) - which more than compensate for having the least amount of sunshine of all counties. South Yorkshire, by contrast, has a QOL rank sixteen places below its air quality position. This is due to a combination of low sunshine, high unemployment and poor nursery provision.

As a check on the robustness of the results, we computed an alternative QOL ranking based upon the implicit prices reported in column 4 of Table 1. The two rankings are broadly consistent, with a Spearman rank correlation coefficient of 0.98 . This is evident both at the top, where eight counties appear in the top ten of both rankings, and at the bottom, where it 
Table 4: Overall Quality of Life and Component Rankings

\begin{tabular}{|c|c|c|c|c|c|c|}
\hline \multirow[t]{2}{*}{ County } & \multirow{2}{*}{$\begin{array}{l}\text { Ranking } \\
\text { by QOL }\end{array}$} & \multicolumn{5}{|c|}{ Component Ranking } \\
\hline & & PM10 & Sunshine & $\begin{array}{c}\text { Nursery } \\
\text { Places }\end{array}$ & $\begin{array}{c}\text { Popn } \\
\text { Density }\end{array}$ & Unemp \\
\hline Cumbria & 1 & 1 & 51 & 29 & 51 & 26 \\
\hline Dyfed & 2 & 3 & 27 & 41 & 53 & 38 \\
\hline Somerset & 3 & 8 & 12 & 11 & 46 & 20 \\
\hline Gwynedd & 4 & 4 & 45 & 44 & 52 & 48 \\
\hline Northumberland & 5 & 2 & 46 & 51 & 54 & 47 \\
\hline Clwyd & 6 & 9 & 42 & 9 & 42 & 23 \\
\hline Devon & 7 & 7 & 9 & 35 & 44 & 35 \\
\hline W. Glamorgan & 8 & 12 & 30 & 39 & 18 & 36 \\
\hline Powys & 9 & 11 & 54 & 14 & 55 & 4 \\
\hline Corwall & 10 & 6 & 5 & 42 & 47 & 49 \\
\hline S. Glamorgan & 11 & 20 & 14 & 23 & 8 & 31 \\
\hline Mid-Glamorgan & 12 & 10 & 31 & 53 & 15 & 46 \\
\hline Lancashire & 13 & 18 & 47 & 2 & 17 & 19 \\
\hline Hereford \& Worcester & 14 & 15 & 33 & 1 & 40 & 18 \\
\hline Dorset & 15 & 14 & 4 & 25 & 32 & 27 \\
\hline Durham & 16 & 5 & 52 & 48 & 36 & 41 \\
\hline Cheshire & 17 & 17 & 44 & 10 & 22 & 17 \\
\hline Shropshire & 18 & 16 & 43 & 17 & 48 & 14 \\
\hline N. Yorkshire & 19 & 13 & 48 & 18 & 50 & 10 \\
\hline Avon & 20 & 25 & 11 & 15 & 11 & 25 \\
\hline Gwent & 21 & 19 & 22 & 52 & 31 & 40 \\
\hline Greater Manchester & 22 & 44 & 55 & 8 & 6 & 33 \\
\hline Gloucestershire & 23 & 26 & 24 & 6 & 38 & 28 \\
\hline Merseyside & 24 & 43 & 34 & 28 & 4 & 53 \\
\hline Wiltshire & 25 & 24 & 16 & 33 & 43 & 6 \\
\hline Tyne and Wear & 26 & 29 & 38 & 36 & 5 & 51 \\
\hline Staffordshire & 27 & 27 & 49 & 12 & 25 & 21 \\
\hline Isle of Wight & 28 & 23 & 1 & 54 & 30 & 52 \\
\hline
\end{tabular}


Table 4: continued

\begin{tabular}{|c|c|c|c|c|c|c|}
\hline \multirow[t]{2}{*}{ County } & \multirow{2}{*}{$\begin{array}{l}\text { Ranking } \\
\text { by QOL }\end{array}$} & \multicolumn{5}{|c|}{ Component Ranking } \\
\hline & & PM10 & Sunshine & $\begin{array}{c}\text { Nursery } \\
\text { Places }\end{array}$ & $\begin{array}{c}\text { Popn } \\
\text { Density }\end{array}$ & Unemp \\
\hline Derbyshire & 29 & 22 & 50 & 30 & 27 & 34 \\
\hline Inner London & 30 & 55 & 17 & 5 & 1 & 55 \\
\hline Humberside & 31 & 21 & 29 & 37 & 33 & 44 \\
\hline W. Yorkshire & 32 & 30 & 53 & 21 & 7 & 29 \\
\hline E. Sussex & 33 & 37 & 2 & 27 & 24 & 45 \\
\hline W. Sussex & 34 & 38 & 3 & 38 & 26 & 7 \\
\hline Oxfordshire & 35 & 41 & 25 & 13 & 37 & 2 \\
\hline W. Midlands & 36 & 53 & 40 & 7 & 3 & 43 \\
\hline Cleveland & 37 & 28 & 39 & 24 & 9 & 54 \\
\hline Cambridgeshire & 38 & 36 & 20 & 19 & 39 & 8 \\
\hline Hampshire & 39 & 39 & 7 & 45 & 21 & 16 \\
\hline Northamptonshire & 40 & 35 & 35 & 16 & 34 & 12 \\
\hline Warwickshire & 41 & 42 & 36 & 20 & 35 & 11 \\
\hline Leicestershire & 42 & 32 & 37 & 32 & 28 & 15 \\
\hline Nottinghamshire & 43 & 33 & 32 & 34 & 16 & 42 \\
\hline Lincolnshire & 44 & 34 & 21 & 26 & 49 & 30 \\
\hline Buckinghamshire & 45 & 40 & 28 & 40 & 29 & 5 \\
\hline Kent & 46 & 50 & 6 & 3 & 23 & 37 \\
\hline S. Yorkshire & 47 & 31 & 41 & 50 & 10 & 50 \\
\hline Berkshire & 48 & 52 & 19 & 22 & 13 & 3 \\
\hline Surrey & 49 & 51 & 15 & 47 & 12 & 1 \\
\hline Essex & 50 & 49 & 10 & 31 & 20 & 39 \\
\hline Hertfordshire & 51 & 48 & 23 & 43 & 14 & 9 \\
\hline Outer London & 52 & 54 & 18 & 4 & 2 & 32 \\
\hline Suffolk & 53 & 46 & 8 & 49 & 41 & 13 \\
\hline Norfolk & 54 & 45 & 13 & 46 & 45 & 24 \\
\hline Bedfordshire & 55 & 47 & 26 & 55 & 19 & 22 \\
\hline
\end{tabular}


is same ten counties that have the lowest QOL indices.

Notwithstanding this robustness with regard to specification, the QOL ranking must be treated with caution. First, the housing data permitted only a limited degree of control for quality differences. This contrasts with the highly detailed information on individuals' personal and job characteristics. Second, there may be important regional variations that are not captured by our set of amenities. QOL indices based on a different set of locational traits could potentially generate a substantially different ranking. Third, the implicit prices are based on an assumption regarding the "marginal" household - the household that is indifferent between locations. In common with previous work, we have taken this to be the household with the sample mean values of hours per worker and workers per household. Finally, the implicit prices are defined for small changes in locational attributes and therefore estimates of willingness to pay for substantial improvements in amenity levels are approximations.

\section{Conclusions}

In this paper we have applied an extended version of Roback's (1982) general equilibrium location model to individual and county level data from England and Wales to estimate implicit prices for a variety of locational attributes. We found positive prices for population density, nursery provision and hours of sunshine, and negative prices for air pollution and unemployment. The implicit prices were used to compute an overall Quality of Life index value for each of the counties. For the representative household, the difference in Quality of Life between the top-ranked and bottom-ranked county was estimated at $£ 2363$ per year. The highest ranked counties are characterised by low levels of airborne particulates and population density, but are heterogeneous in other respects. Those at the bottom of the ranking exhibited even more variety, having only high levels of airborne particulates in common.

We have emphasised that the implicit prices and associated Quality of Life index values should be treated with caution but, being derived from the actual decisions of agents, they may constitute a useful counterpoint to quality of life assessments based on subjective valuations. 


\section{Appendix}

The source and description of each variable used in the estimations is given in Table 5. Table 6 gives a description of the variables representing personal characteristics of individuals. These variables were included in the wage equation. Table 7 provides the Box-Cox FIML coefficients estimates for all the variables used in the estimations.

\section{Likelihood Ratio Test}

To test if the amenities were jointly significant in each equation a likelihood ratio test was carried out. In the wage equation, the restricted model was one which only contained the constant and personal characteristics as explanatory variables. In the housing equation, the restricted model was one which contained the constant and the property dummies as explanatory variables. The null hypothesis of the coefficients on the amenities being jointly equal to zero was tested against the alternative that at least one of the amenity coefficients was not equal to zero.

The likelihood value from the restricted model was calculated in two ways. (a) The BoxCox value for $\lambda$ (see Equation (7)) in the restricted model was kept at that which maximised the likelihood value of the unrestricted model. (b) The Box-Cox value for $\lambda$ restricted model was kept at that which maximised the likelihood value of the restricted model.

Thus two likelihood ratio tests were conducted for each equation as represented by Columns $(1),\left(1^{\prime}\right),(2)$ and $\left(2^{\prime}\right)$ in Table 1 . Using critical values of $\chi_{9}^{2,0.01}=21.66$ and $\chi_{5}^{2,0.01}=15.09$ the null hypothesis was rejected in the direction of the alternative for all equations.

\section{Acknowledgements}

$P M_{10}$ data has been made available by the Department of the Environment, Transport and the Regions and AEA Technology, National Environmental Technology Centre.

The climate data has been supplied by the Climatic Research Unit, University of East Anglia (Climate Impacts LINK Project, Department of the Environment Contract EPG 1/1/16) on behalf of the Hadley Centre and the Meteorological Office.

Material from the Quarterly Labour Force Surveys is Crown copyright; has been made available by the Office of National Statistics through The Data Archive and has been used by 
permission. Neither the ONS nor The Data Archive bear any responsibility for the analysis or interpretation of the data reported here. 
Table 5: Data Description: Main Variables

\begin{tabular}{|c|c|c|c|c|c|}
\hline $\begin{array}{l}\text { Variable } \\
\text { Name }\end{array}$ & Source & $\begin{array}{l}\text { Raw Data } \\
\text { Definition }\end{array}$ & $\begin{array}{l}\text { Variable used } \\
\text { in estimation }\end{array}$ & $\begin{array}{l}\text { Sample } \\
\text { Period }\end{array}$ & $\begin{array}{c}\text { Estimating Variable } \\
\text { Mean }\end{array}$ \\
\hline $\mathbf{P M}_{\mathbf{1 0}}$ (particulates) & AEA Technology & $\begin{array}{l}\mu g m^{-3} \text {, annual means, grid data } \\
(1 \mathrm{~km})\end{array}$ & $\begin{array}{l}\mu g m^{-3}, \text { annual } \\
\text { mean, by county }\end{array}$ & 1994 & 17.22 \\
\hline Sunshine & $\begin{array}{l}\text { Climatic Research } \\
\text { Unit, UEA }\end{array}$ & $\begin{array}{l}\text { Sunshine hours (hours x 10) av- } \\
\text { eraged over 1961-1990, by month; } \\
\text { grid data (mean altitude values) (10 } \\
\mathrm{km})\end{array}$ & $\begin{array}{l}\text { Annual sunshine } \\
\text { hours, by county }\end{array}$ & $\begin{array}{l}\text { Average } \\
1961-1990\end{array}$ & 1429 \\
\hline Precipitation & $\begin{array}{l}\text { Climatic Research } \\
\text { Unit, UEA }\end{array}$ & $\begin{array}{l}\text { Preciptation ( } \mathrm{mm} \times 10) \text { averaged } \\
\text { over } 1961-1990, \text { by month; grid } \\
\text { data (mean altitude values) }(10 \mathrm{~km})\end{array}$ & $\begin{array}{l}\text { Annual precipita- } \\
\text { tion }(\mathrm{mm}), \text { by } \\
\text { county }\end{array}$ & $\begin{array}{l}\text { Average } \\
1961-1990\end{array}$ & 872.78 \\
\hline Frost Days & $\begin{array}{l}\text { Climatic Research } \\
\text { Unit, UEA }\end{array}$ & $\begin{array}{l}\text { Frost days (days x 10) averaged } \\
\text { over 1961-1990, by month; grid } \\
\text { data (mean altitude values) }(10 \mathrm{~km})\end{array}$ & $\begin{array}{l}\text { Annual frost } \\
\text { days, by county }\end{array}$ & $\begin{array}{l}\text { Average } \\
1961-1990\end{array}$ & 103 \\
\hline Temperature & $\begin{array}{l}\text { Climatic Research } \\
\text { Unit, UEA }\end{array}$ & $\begin{array}{l}\text { Degrees centigrade averaged over } \\
\text { 1961-1990, by month; grid data } \\
\text { (mean altitude values) }(10 \mathrm{~km})\end{array}$ & $\begin{array}{l}\text { Annual average } \\
\text { temperature, by } \\
\text { county }\end{array}$ & $\begin{array}{l}\text { Average } \\
1961-1990\end{array}$ & 8 \\
\hline Pupil-Teacher Ratio & Regional Trends 1996 & $\begin{array}{l}\text { Primary and Secondary school ra- } \\
\text { tios, by county }\end{array}$ & $\begin{array}{l}\text { Average Pupil- } \\
\text { Teacher ratio }\end{array}$ & $1994 / 95$ & 19.7 \\
\hline Nursery Places & Regional Trends 1996 & $\begin{array}{l}\text { Day nursery places per } 1000 \text { popu- } \\
\text { lation aged under } 5 \text { years, by county }\end{array}$ & Nursery Places & $\begin{array}{l}\text { March } \\
1994\end{array}$ & 38.7 \\
\hline
\end{tabular}


Table 5: continued

\begin{tabular}{|c|c|c|c|c|c|}
\hline $\begin{array}{l}\text { Variable } \\
\text { Name }\end{array}$ & Source & $\begin{array}{l}\text { Raw Data } \\
\text { Definition }\end{array}$ & $\begin{array}{l}\text { Variable used } \\
\text { in estimation }\end{array}$ & $\begin{array}{l}\text { Sample } \\
\text { Period }\end{array}$ & $\begin{array}{c}\text { Estimating Variable } \\
\text { Mean }\end{array}$ \\
\hline Population Density & $\begin{array}{l}\text { Key Population and } \\
\text { Vital Statistics } 1994 \\
\text { (for population); Re- } \\
\text { gional Trends } 1995 \\
\text { (for area) }\end{array}$ & $\begin{array}{l}\text { Resident population mid } 1994 \text { and } \\
\text { area (sq km) for } 1993 \text {, by county; } \\
\text { we assume that the area has not } \\
\text { changed from } 1993 \text { to } 1994\end{array}$ & $\begin{array}{l}\text { Population } \\
\text { density (popu- } \\
\text { lation/area) in } \\
\text { persons per sq } \\
\text { km }\end{array}$ & mid-1994 & 693.0 \\
\hline Unemployment & $\begin{array}{l}\text { Regional Trends } \\
\text { 1995; Employment } \\
\text { Gazette } 1995\end{array}$ & $\begin{array}{l}\text { Claimant unemployment rate Jan- } \\
\text { uary 1995, by county; rates for Sur- } \\
\text { rey, Inner and Outer London have } \\
\text { been calculated using Employment } \\
\text { Gazette }\end{array}$ & $\begin{array}{l}\text { Unemployment } \\
\text { rate }(\%)\end{array}$ & $\begin{array}{l}\text { January } \\
1995\end{array}$ & 8.6 \\
\hline Wages & $\begin{array}{l}\text { Quarterly Labour } \\
\text { Force Survey }\end{array}$ & $\begin{array}{l}\text { Grsswk: earnings; gross weekly pay } \\
\text { in main job; of employees and those } \\
\text { on government training schemes. } \\
\text { Self-employed are excluded. Hours } \\
\text { worked per week is bushr (total } \\
\text { hours, excl overtime) }+ \text { pothr (over- } \\
\text { time hours) }\end{array}$ & $\begin{array}{l}\text { weekly pay per } \\
\text { hour in main job; } \\
\text { (employees only) }\end{array}$ & $\begin{array}{l}1995 \\
q 2, q 3, q 4\end{array}$ & 8.12 \\
\hline Housing Expenditure & $\begin{array}{l}\text { HM Land Registry; } \\
\text { Financial } \\
1997\end{array}$ & $\begin{array}{l}\text { Avg price of residential property } \\
\text { sales completed quarterly by prop- } \\
\text { erty type; Avg building society } \\
\text { mortgage rate }\end{array}$ & $\begin{array}{l}\text { Avg annual ex- } \\
\text { penditure by } \\
\text { property type }\end{array}$ & $\begin{array}{l}\text { April 95- } \\
\text { March } 96\end{array}$ & 4703.32 \\
\hline Property Type & computed & $\begin{array}{l}\text { Detached, semi-detached, terraced, } \\
\text { flat/maisonette }\end{array}$ & Dummy variables & & \\
\hline
\end{tabular}


Table 6: Data Description: Personal Characteristics in Wage Equation

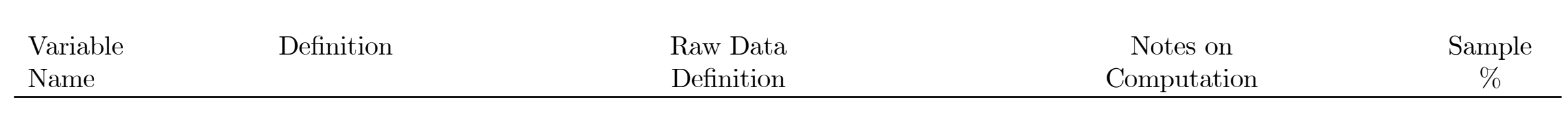

All variables have been extracted from the Quarterly Labour Force Surveys 1995 q2,q3,q4.
Male $\quad 1$ if male, 0 otherwise
sex: Gender of individual
Head 1 if head, 0 otherwise relhoh: Relationship to head of household
White 1 if white, 0 otherwise ethcen: Ethinicity of person
Married 1 if married, 0 otherwise marstt: Marital status of person
YSchool years of full-time education
Exper years of post-education ex- perience
continuously employed)
edage: Age when completed full- time education
Yschool $=$ edage $-5($ age when started school)
For individuals who are still in full-time education and earning a wage we use empmom. For those who have been been in education we use (age - 15). For the remainder we use (age - edage).
exper*exper
Expersq experience squared

Parttime 1 if part-time, 0 if full-time 
Table 6: continued

\begin{tabular}{llll}
\hline \hline $\begin{array}{l}\text { Variable } \\
\text { Name }\end{array}$ & Definition & $\begin{array}{l}\text { Raw Data } \\
\text { Definition }\end{array}$ & $\begin{array}{c}\text { Notes on } \\
\text { Computation }\end{array}$ \\
\hline Private & 1 if private, 0 if public & $\begin{array}{l}\text { public: } \\
\text { public or private sector }\end{array}$ & 71.7
\end{tabular}

\section{INDUSTRY mix}

\section{Agrifish}

1 if agriculture or fishing, 0 otherwise

$\begin{array}{ll}\text { Enerwater } & 1 \text { if mining,quarrying or } \\ \text { Manu } & \text { electricity, 0 otherwise } \\ & 1 \text { if manufacturing, } 0 \text { other- } \\ \text { Constrn } & \text { wise } \\ & 1 \text { if construction, } 0 \text { otherwise }\end{array}$

Disthotl 1 if wholesale,retail, motor trade, hotels or restaurants, 0 otherwise

Transcom 1 if transport storage or communications, 0 otherwise

Bankins 1 if financial intermediation, real estate or business activities, 0 otherwise

Pubadotrser 1 if public administration, defence, education, health or other services, 0 otherwise
More categories than required, hence the aggregation. The aggregation has been done using codes on page 66 and 68 of 1996 QLFS Q3, vol 2

inds92m: Industry division in main job

inds92m: Industry division in main job

inds92m: Industry division in main job

inds92m: Industry division in main job

inds92m: Industry division in main job

inds92m: Industry division in main job

inds92m: Industry division in main job

inds92m: Industry division in main job 
Table 6: continued

\begin{tabular}{|c|c|c|c|c|}
\hline $\begin{array}{l}\text { Variable } \\
\text { Name }\end{array}$ & Definition & $\begin{array}{l}\text { Raw Data } \\
\text { Definition }\end{array}$ & $\begin{array}{c}\text { Notes on } \\
\text { Computation }\end{array}$ & $\begin{array}{c}\text { Sample } \\
\% \\
\end{array}$ \\
\hline \multicolumn{3}{|c|}{ OCCUPATION mix } & $\begin{array}{l}\text { Some aggregation has been done. } \\
\text { Mapping done using the occupational } \\
\text { breakdown section in } 1996 \text { QLFS Q3, } \\
\text { vol } 5\end{array}$ & \\
\hline Profssn & 1 if professional, 0 otherwise & $\begin{array}{l}\text { socmajm: major occupation group } \\
\text { in main job }\end{array}$ & & 41.8 \\
\hline Whcollar & 1 if whitecollar, 0 otherwise & $\begin{array}{l}\text { socmajm: major occupation group } \\
\text { in main job }\end{array}$ & & 21.4 \\
\hline Blcollar & 1 if bluecollar, 0 otherwise & $\begin{array}{l}\text { socmajm: major occupation group } \\
\text { in main job }\end{array}$ & & 31.1 \\
\hline Labourer & 1 if labourer, 0 otherwise & $\begin{array}{l}\text { socmajm: major occupation group } \\
\text { in main job }\end{array}$ & & 5.7 \\
\hline
\end{tabular}


Table 7: FIML estimates of Wage and Housing Equation

\begin{tabular}{|c|c|c|c|c|}
\hline \multirow[b]{2}{*}{ Variable } & \multicolumn{2}{|c|}{ Wage Equation } & \multicolumn{2}{|c|}{ Housing Equation } \\
\hline & Estimate & t-statistic & Estimate & t-statistic \\
\hline Constant & -0.63370 & 6.10 & 3.85905 & 119.01 \\
\hline Male & 0.154066 & 10.97 & & \\
\hline Head & 0.14783 & 10.62 & & \\
\hline White & 0.24930 & 9.32 & & \\
\hline Married & 0.09240 & 8.52 & & \\
\hline YSchool & 0.07090 & 34.20 & & \\
\hline Exper & 0.04195 & 26.78 & & \\
\hline Expersq & -0.00074 & 24.17 & & \\
\hline Parttime & -0.15320 & 10.80 & & \\
\hline Private & -0.18638 & 13.25 & & \\
\hline Agrifish & -0.19915 & 4.02 & & \\
\hline Enerwater & 0.32538 & 7.82 & & \\
\hline Manu & 0.15064 & 9.03 & & \\
\hline Constrn & 0.09858 & 3.58 & & \\
\hline Disthotl & -0.09192 & 5.31 & & \\
\hline Transcom & 0.07850 & 4.01 & & \\
\hline Bankins & 0.20700 & 12.60 & & \\
\hline Profssn & 0.61837 & 26.02 & & \\
\hline Whcollar & 0.24655 & 10.02 & & \\
\hline Blcollar & 0.16102 & 6.79 & & \\
\hline Detached & & & 0.15816 & 31.47 \\
\hline Semidetached & & & 0.05851 & 10.56 \\
\hline Terraced & & & 0.01036 & 2.13 \\
\hline $\mathrm{PM}_{10}$ (particulates) & .03200 & 7.60 & 0.00031 & 0.20 \\
\hline Sunshine & .00020 & 4.18 & 0.00015 & 6.77 \\
\hline Nursery Places & -.00056 & 1.73 & -0.00001 & -0.05 \\
\hline Population Density & .00003 & 4.30 & 0.00003 & 10.52 \\
\hline Unemployment Rate & -.01850 & 6.65 & -0.01147 & -12.08 \\
\hline No of Observations & & 320 & & 220 \\
\hline Log likelihood & -300 & 67.40 & & -1724.93 \\
\hline
\end{tabular}

In the wage equation, the omitted industry is "public administration and other services" and the omitted occupation is "labourer".

In the housing equation, the omitted property type is "flat/maisonette". 


\section{References}

Blomquist, G.C., Berger, M.C. and Hoehn, J.P. (1988). 'New Estimates of the Quality of Life in Urban Areas.' American Economic Review, vol. 78, pp. 89-107.

Clarke, D.E. and Nieves, L.A. (1994). 'An Interregional Hedonic Analysis of Noxious Facility Impacts on Local Wages and Property Values.' Journal of Environmental Economics and Management, vol. 27, pp. 235-53.

Department of the Environment, Transport and the Regions (1999). A Better Quality of Life: A Strategy for Sustainable Development in the United Kingdom. TSO, London. Command number 4345.

Gyourko, J. and Tracy, T. (1991). 'The Structure of Local Public Finance and the Quality of Life.' Journal of Political Economy, vol. 99, pp. 774-806.

Maddison, D. (1997). 'Measuring the Impact of Climate Change on Britain.' unpublished PhD thesis, University of Strathclyde.

Nordhaus, W. and Tobin, J. (1972). 'Is Growth Obsolete?' In Economic Growth. New York: National Bureau of Economic Research.

Ridker, G. and Henning, J.A. (1967). 'The Determinants of Residential Property Values with Special Reference to Air Pollution.' Review of Economics and Statistics, vol. 49, pp. $246-57$.

Roback, J. (1982). 'Wages, Rents, and the Quality of Life.' Journal of Political Economy, vol. 90 , pp. 1257-1278.

Rosen, S. (1974). 'Hedonic Prices and Implicit Markets: Product Differentiation in Pure Competition.' Journal of Political Economy, vol. 82, pp. 34-55.

Rosen, S. (1979). 'Wage-Based Indexes of Urban Quality of Life.' In Current Issues in Urban Economics (eds. P. Mieszkowski and M. Straszheim). Baltimore: Johns Hopkins University Press. 
Stedman, J. Campbell, G and Vincent, K. (1997). 'Estimated High Resolution Maps of Background Air Pollutant Concentrations in the UK.' AEA/RAMP/20008001/003. 